DOI: $\square$ https://doi.org/10.15407/techned2020.03.040

\title{
COMPARATIVE ANALYSIS OF PASSIVE, ACTIVE AND HYBRID CURRENT HARMONICS FILTERS FOR FREQUENCY-REGULATED ELECTRIC DRIVE
}

Journal

Publisher

ISSN

Issue

Pages
Tekhnichna elektrodynamika

Institute of Electrodynamics National Academy of Science of Ukraine 1607-7970 (print), 2218-1903 (online)

No 3, 2020 (May/June)

$40-45$

\section{Authors}

I.V. Volkov ${ }^{1 \star}$, S.V. Podolny ${ }^{2 \star \star}$, Yu.V. Marunya ${ }^{1 \star \star \star}$

1- Institute of Electrodynamics of the National Academy of Sciences of Ukraine,

56 Peremohy Ave., Kyiv, 03057, Ukraine,

e-mail: ig.volkov@ukr.net

2. Sentinel Power Quality FZE, UAE

* ORCID ID : https://orcid.org/0000-0002-0696-0382

** ORCID ID : https://orcid.org/0000-0001-8111-0858

*** ORCID ID : https://orcid.org/0000-0003-0071-1702

\section{Abstract}

The analysis of three types of harmonic filters of the mains current used in power supply systems of asynchronous electric drives with frequency control is carried out. Mathematical modeling of a typical version of such a system is carried out, supplying an electric drive with a capacity of $250 \mathrm{~kW}$ from an industrial network of $0.4 \mathrm{kV}, 50 \mathrm{~Hz}$. The spectrograms and diagrams of the current of the active and hybrid filters are compared and significant differences in the values of the transistor currents necessary for the same level of harmonic suppression are determined. The main factors affecting the pricing and optimization of reactive and semiconductor elements are described. A significant effect of the relationship between the reactivity of the short circuit of the network and the additional reactor of the hybrid filter on its efficiency and cost has been established. References 11, Figures 6, Table 1.

Key words: current harmonic ratio, THDi, passive filter, active parallel-type filter, hybrid filter, 
electric drive, distortion compensation.

Received: 27.01.2020

Accepted: 28.02.2020

Published: 05.05.2020

\section{References}

1. Zharkin A.F., Novsky V.A., Palachev S.A. Regulatory and technical aspects of ensuring standard voltage characteristics in power supply systems of Ukraine. Vistnyk NTU KhPI. 2012. No. 52. Pp. 76-83. (Rus)

2. Braslavsky I.Ya. Energy-saving asynchronous electric drive. Moskva: Academy, 2004. 256 p. (Rus)

3. Siemens drive option partner. URL: https://siemens-product-partner.schaffner.com (Accessed at 20.01.2020).

4. AC Drives. URL: https://www.danfoss.com/en/products/ac-drives/?sort=default sort (Accessed at 20.01.2020).

5. High-voltage capacitors and filters. URL: https://new.abb.com/high-voltage/capacitors/hv (Accessed at 20.01.2020).

6. Proper selection of passive and active power quality filters for the mitigation of mains harmonics. URL: https://www.eetimes.com/proper-selection-of-passive-and-active-power-quali ty-filters-for-the-mitigation-of-mains-harmonics/

(Accessed at 20.01.2020).

7. Active dynamic harmonic filters Comsys. URL: http://www.esto.pro/comsys adf (Accessed at 20.01.2020). (Rus)

8. Lam C. S., Wong M.C. Design and Control of Hybrid Active Power Filters. Springer, 2014. 217 p. DOI: https://doi.org/10.1007/978-3-642-41323-0

9. Levin M., Volkov I. Universal harmonic mitigating system. Patent USA 6127743, 2000.

10. Levin M., Volkov I. Combined harmonic filter and phase converter. Patent USA 2006/0197385b A1, 2006.

11. Elhand transformatory. URL: https://ru.elhand.pl/ (Accessed at 20.01.2020). 


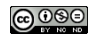

This work is licensed under a Creative Commons Attribution-NonCommercial-NoDerivatives $\underline{4.0 \text { International License }}$ 